10-23-2015

\title{
Ethanol Pharmacokinetics in Neonates Secondary to Medication Administration
}

\author{
Elizabeth Marek, PharmD \\ Thomas Jefferson University \\ Susan C. Adeniyi-Jones, MD \\ Thomas Jefferson University \\ Lindsey Roke, PharmD \\ Thomas Jefferson University \\ Tara E. DeCerbo, PharmD \\ Thomas Jefferson University \\ Rebecca L. Cordell, PharmD \\ Fqliom thisephdadsonditiminal sityrks at: https://jdc.jefferson.edu/petposters \\ Part of the Pharmacy and Pharmaceutical Sciences Commons

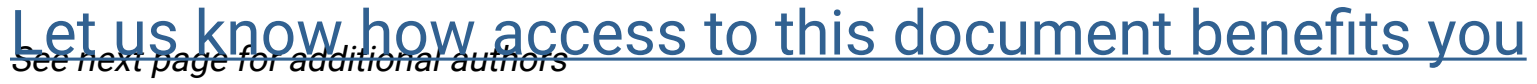

\section{Recommended Citation}

Marek, PharmD, Elizabeth; Adeniyi-Jones, MD, Susan C.; Roke, PharmD, Lindsey; DeCerbo, PharmD, Tara E.; Cordell, PharmD, Rebecca L.; Monks, PharmD, Paul S.; and Kraft, MD, Walter K., "Ethanol Pharmacokinetics in Neonates Secondary to Medication Administration" (2015). Department of Pharmacology and Experimental Therapeutics Posters. 1.

https://jdc.jefferson.edu/petposters/1

This Article is brought to you for free and open access by the Jefferson Digital Commons. The Jefferson Digital Commons is a service of Thomas Jefferson University's Center for Teaching and Learning (CTL). The Commons is a showcase for Jefferson books and journals, peer-reviewed scholarly publications, unique historical collections from the University archives, and teaching tools. The Jefferson Digital Commons allows researchers and interested readers anywhere in the world to learn about and keep up to date with Jefferson scholarship. This article has been accepted for inclusion in Department of Pharmacology and Experimental Therapeutics Posters by an authorized administrator of the Jefferson Digital Commons. For more information, please contact: JeffersonDigitalCommons@jefferson.edu. 


\section{Authors}

Elizabeth Marek, PharmD; Susan C. Adeniyi-Jones, MD; Lindsey Roke, PharmD; Tara E. DeCerbo, PharmD; Rebecca L. Cordell, PharmD; Paul S. Monks, PharmD; and Walter K. Kraft, MD 
